\title{
RESULTS FOR THE THIRD QUARTER 2007 TANK 50H WAC SLURRY SAMPLE: CHEMICAL AND RADIONUCLIDE CONTAMINANT RESULTS
}

Kristine E. Zeigler

Ned E. Bibler

July 2008

Savannah River National Laboratory

Aiken, SC 29808

Prepared for the U.S. Department of Energy Under Contract Number DEAC09 08SR22470

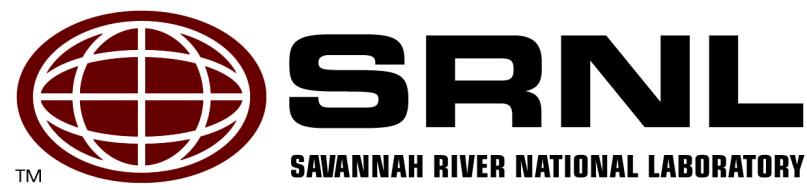




\section{DISCLAIMER}

This work was prepared under an agreement with and funded by the U.S. Government. Neither the U.S. Government or its employees, nor any of its contractors, subcontractors or their employees, makes any express or implied: 1. warranty or assumes any legal liability for the accuracy, completeness, or for the use or results of such use of any information, product, or process disclosed; or 2. representation that such use or results of such use would not infringe privately owned rights; or 3. endorsement or recommendation of any specifically identified commercial product, process, or service. Any views and opinions of authors expressed in this work do not necessarily state or reflect those of the United States Government, or its contractors, or subcontractors.

This document was prepared in conjunction with work accomplished under Contract No. DEAC09-08SR22470 with the U.S. Department of Energy. 


\begin{tabular}{|l|l|l|l|}
\hline $\begin{array}{l}\text { Revision } \\
\text { Number: }\end{array}$ & $\begin{array}{l}\text { Page } \\
\text { Number: }\end{array}$ & Date: & Revision: \\
\hline 1 & $5-8,10-12$ & $07 / 08$ & Original Issue \\
\hline Correction of ICP-MS values at detection \\
limit of instrument. See below for \\
explanation.
\end{tabular}

This is Revision 1 of the original WSRC-TR-2008-00080, "Results For The Third Quarter 2007 Tank 50H WAC Slurry Sample: Chemical and Radionuclide Contaminant Results." The following are changes to the original document:

- ICP-MS data for isotopes at the detection limit of the instrument (less than values), were originally incorrectly calculated; however, the corrected ICP-MS values are still less than values and none exceed the WAC limit or target. The corrected less than values are for Co (Table 3-2), Th-229 (Table 3-4), Th-230 (Table 3-4), U-233 (Table 3-3), U-234 (Table 3-4), Np-237 (Table 3-4), Pu-242 (Table 3-4), Pu-244 (Table 3-4) and Th (Table 3-6).

- The total gamma concentration has been recalculated to include Co-60 and not Ba-137m. This has been addressed in the text portion of the document (page 10) and also in Table 3-6 and Table 3-7. 
WSRC-TR-2008-00080

Revision 1

This page intentionally left blank 
Key Words:

Tank 50

Waste Acceptance Criteria (WAC)

Saltstone

\section{RESULTS FOR THE THIRD QUARTER 2007 TANK 50H WAC SLURRY SAMPLE: CHEMICAL AND RADIONUCLIDE CONTAMINANT RESULTS}

Kristine E. Zeigler

Ned E. Bibler

July 2008

Savannah River National Laboratory

Aiken, SC 29808

Prepared for the U.S. Department of Energy Under Contract Number

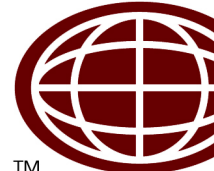




\section{AUTHORS:}

\section{REVIEWS AND APPROVALS}

Kristine E. Zeigler, Analytical Development

Date

Ned E. Bibler, Process Science \& Engineering

Date

\section{TECHNICAL REVIEWER:}

Alex D. Cozzi, Process Science \& Engineering

Date

Blythe M. Ashcraft, Analytical Development

Date

\section{APPROVERS:}

John E. Occhipinti, Manager, Process Cognizant Engineering

Date

Caroline L. Atseff, HTF Chief Engineering

Date

Aaron V. Staub, Process Cognizant Engineering

Date

Lori M. Chandler, Manager, Analytical Development

Date

Allan B. Barnes, Manager, Engineering Process Development

Date 


\section{EXECUTIVE SUMMARY}

This report presents the chemical and radionuclide contaminant results for the characterization of the Third Quarter sampling of Tank $50 \mathrm{H}$ for the Saltstone Waste Acceptance Criteria (WAC). ${ }^{1}$ The information from this characterization will be fed to Waste Solidification Engineering to support the transfer of aqueous waste to the Saltstone Facility, that is the transfer of Tank 50H to the Salt Feed Tank (SFT) in Z-area. This information is also used by Liquid Waste-Process Engineering to update the Tank 50 Waste Characterization System (WCS).

The following conclusion is drawn from the analytical results found in this report:

- None of the results exceeded the WAC targets or limits. Nitrate and manganese, did not exceed the WAC but were nominally within a factor of 3 of the WAC limits. 


\section{TABLE OF CONTENTS}

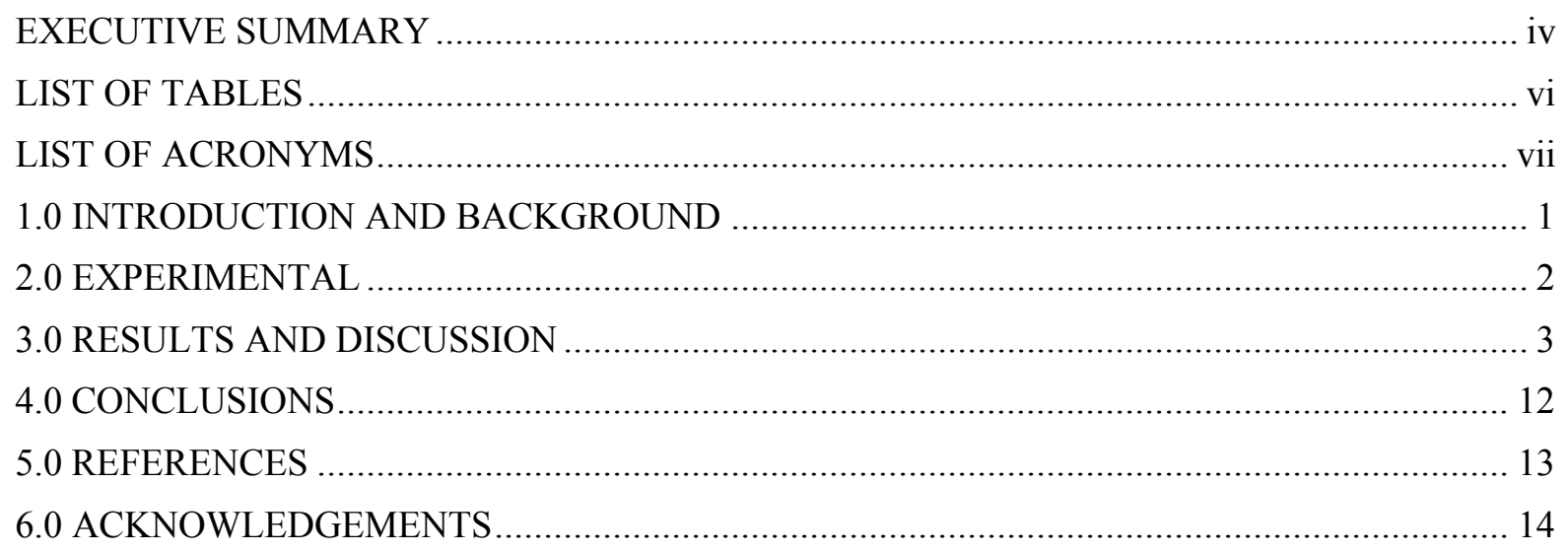




\section{LIST OF TABLES}

Table 3-1. Results for the 3rd Quarter 2007 Tank 50 Slurry Samples and WAC Limits for Chemical Contaminants Listed in Attachment 8.1 of the Saltstone WAC, Revision 7

Table 3-2. Results for the 3rd Quarter 2007 Tank 50 Slurry Samples and WAC Targets for Chemical Contaminants Listed in Attachment 8.2 of the Saltstone WAC, Revision 7

Table 3-3. Results for 3rd Quarter 2007 Tank 50 Slurry Samples and WAC Limits for Radionuclide Contaminants Listed in Attachment 8.3 of the Saltstone WAC, Revision 7.......... 6

Table 3-4. Results for 3rd Quarter 2007 Tank 50 Slurry Samples and WAC Targets for Radionuclide Contaminants Listed in Attachment 8.4 of the Saltstone WAC, Revision 7........... 7

Table 3-5. Results for the 3rd Quarter 2007 Slurry Samples for the Saltstone Processing Criteria WAC Limits, Listed in Table 4 of the Saltstone WACS, Revision 7.

Table 3-6. Requests for constituents for TCLP/UHC support as well as from the TTR for Tank 50 Slurry Samples

Table 3-7. Requests from the WSE for Corrosion Species from Tank 50 Slurry Samples. 


\section{LIST OF ACRONYMS AND ABBREVIATIONS}

$\begin{array}{ll}\text { AD } & \text { Analytical Development } \\ \text { AA } & \text { Atomic absorption (spectroscopy) } \\ \text { DI } & \text { Deionized } \\ \text { ETP } & \text { Effluent Treatment Project } \\ \text { HLW } & \text { High level waste } \\ \text { HPLC } & \text { High Performance Liquid Chromatography } \\ \text { IC } & \text { Ion chromatography } \\ \text { ICP-ES } & \text { Inductively coupled plasma - (atomic) emission spectroscopy } \\ \text { ICP-MS } & \text { Inductively coupled plasma - mass spectroscopy } \\ \text { MDL } & \text { method detection limit } \\ \text { ND } & \text { Not determined } \\ \text { pCi/mL } & \text { picoCuries per milliliter } \\ \text { RSD } & \text { Relative standard deviation } \\ \text { SDF } & \text { Saltstone Disposal Facility } \\ \text { SFT } & \text { Salt Feed Tank } \\ \text { SPF } & \text { Saltstone Production Facility } \\ \text { SRNL } & \text { Savannah River National Laboratory } \\ \text { SVOA } & \text { Semi-volatile organic analysis } \\ \text { TCLP/UHC } & \text { Toxic Characterization Leaching Procedure/Underlying Hazardous } \\ & \text { Constituent } \\ \text { TTR } & \text { Technical task request } \\ \text { TIC/TOC } & \text { Total inorganic carbon/total organic carbon } \\ \text { VOA } & \text { Volatile organic analysis } \\ \text { WAC } & \text { Waste Acceptance Criteria } \\ \text { WSE } & \text { Waste Solidification Engineering } \\ \text { Wt \% } & \text { Weight percent }\end{array}$




\subsection{INTRODUCTION AND BACKGROUND}

The Saltstone Facility is designed and permitted to immobilize and dispose of low-level radioactive and hazardous liquid waste (salt solution) remaining from the processing of radioactive material at the Savannah River Site. ${ }^{1}$ Low activity wastewater streams from the Effluent Treatment Project (ETP), HCanyon, and the high level waste (HLW) storage tanks, are stored as a mixture in Tank $50 \mathrm{H}$ until it can be pumped to the Saltstone Facility for treatment and disposal. Specific waste acceptance criteria (WAC) must be met for the transfer of low-level aqueous waste from Tank $50 \mathrm{H}$ to the Saltstone Facility. ${ }^{1}$ Low level waste which meets the WAC can be transferred, stored and treated in the Saltstone Production Facility (SPF) for subsequent disposal as saltstone in the Saltstone Disposal Facility (SDF). ${ }^{1}$

Waste Solidification Engineering (WSE) has requested through a Technical Task Request (TTR) ${ }^{2}$ that the Savannah River National Laboratory (SRNL) measure the concentrations of chemical and radionuclide contaminants listed in the currently approved Saltstone Waste Acceptance Criteria (WAC). ${ }^{1}$ A Task Technical and Quality Assurance Plan ${ }^{3}$ and Analytical Study Plan ${ }^{4}$ has been written for this request. WAC determinations are needed on a quarterly basis for chemical contaminants and every first and third quarter for radioactive contaminants. This memorandum presents the results for the chemical and radionuclide contaminants in the third quarter, from the samples taken from Tank 50 in September, 2007. 


\subsection{EXPERIMENTAL}

In Septermer, 2007, six 1 liter slurry samples (designated as Batch 2) were taken from Tank 50 for the third quarter $2007 \mathrm{WAC}$ analyses. An additional $200 \mathrm{~mL}$ sample was taken in a steel bottle specifically for volatile organic analysis. The 1 liter bottles were labeled HFT-50-07-109 through -115. Three of the 1 liter samples appeared to contain a greater quantity of solids compared to the others. Those particular samples were processed for solids analysis to support grout formulations. The weight percent solids of the slurries were identical (average $27.413 \mathrm{wt} \%$ with a standard deviation 0.030 .) Triplicate aliquots of the mixed slurry from bottle 109 were then taken in a radiological hood in SRNL for analyses of the chemical and radionuclide contaminants. Before the aliquots were pulled, the bottle was shaken vigorously to thoroughly mix up the solids in the supernate.

For Total Inorganic Carbon/ Total Organic Carbon (TIC/TOC) analysis and hydroxide analysis, an aliquot was taken in a radiological hood and filtered with a 0.45 micron filter to obtain clear supernate. Three samples were submitted for TIC/TOC and hydroxide analysis.

Three other slurry sample replicates from bottle 109 were each submitted to the AD Ion Chromatography (IC) Laboratory for soluble anion analysis; the AD Organic Analysis Laboratory for high pressure liquid chromatography (HPLC) analysis of tetraphenlyborate and other nonvolatile organic contaminants; and finally the AD Dissolution Laboratory for digestion of the sample.

Triplicate slurry samples of approximately $100-125 \mathrm{~mL}$ were submitted to the Radiochemistry group for appropriate dissolution and analyses.

The separate steel bottle containing $200 \mathrm{~mL}$ of slurry sample was sent for analysis of various organic contaminants by semi volatile and volatile organic analysis (SVOA and VOA, respectively).

Slurry samples sent to the Dissolution Laboratory were digested in a radioactive hood by AD personnel using the aqua regia method to dissolve all the solids. The sample was poured into a preweighed Teflon vessel capable of sealing with a screw cap to hold pressures of $\sim 150$ psia. The weight of the slurry in each vessel was $31.4952,35.8580$, and 32.9132 grams. These samples were each mixed with $9 \mathrm{~mL}$ of concentrated $\mathrm{HCl}$ acid and $3 \mathrm{~mL}$ of concentrated $\mathrm{HNO}_{3}$ acid and capped immediately to tightly seal the vessels. The vessels were then heated for 2 hours in a $110{ }^{\circ} \mathrm{C}$ oven. After the vessels had cooled, they were opened and each digestion solution was diluted to $50 \mathrm{~mL}$ using DI water. No undissolved solids remained in any of the three samples. Aliquots were submitted for inductively coupled plasma-(atomic) emission spectroscopy (ICP-ES), inductively coupled plasma-mass spectroscopy (ICP-MS), atomic absorption spectroscopy (AA) for $\mathrm{Hg}, \mathrm{As}, \mathrm{K}, \mathrm{Na}$, and $\mathrm{Se}$, and also for gamma scan. 


\subsection{RESULTS AND DISCUSSION}

The following tables are the results from the 3rd Quarter WAC analyses. Tables Table 3-1 and Table 3-2 are directly from the WAC, attachments 8.1 and 8.2 respectively, and list the chemical contaminants. Table 3-3 and Table 3-4 contain results for the radioactive contaminants and their targets listed in attachments 8.3 and 8.4 respectively, of the Saltstone WAC, Revision 7. Each table provides the method for determination of the concentration of the contaminant, the average concentration (in the appropriate units) based on triplicate samples of the supernate or dissolved slurry, the \%RSD of the average, and finally the WAC target or limit for the concentration of the contaminant. The concentrations of some of the contaminants were too low to be measured by the analytical method being used. In these instances, the method detection limit (MDL) for the analytical method is given as the maximum concentration of that contaminant that might be in the supernate or slurry. All maximum concentrations calculated in this manner have a less than symbol $(<)$ in front of them in the tables. In all cases these maximum concentrations were less than the WAC target or limit, indicating that the analytical method was indeed sensitive enough to measure whether the concentration of the contaminant was less than the WAC target or limit.

Other tables found in this report include Table 3-5, which shows the WAC Processing Criteria and their associated limits listed in Attachment 4 of the WAC. Table 3-6 contains constituents named in the TTR but not contained in the WAC and also constituents that are used to aid in supporting the EPA Toxic Characterization Leaching Procedure and Underlying Hazardous Constituent work (TCLP/UHC). ${ }^{4}$ The limits listed for the constituents and are much lower than the WAC requirements. Finally, Table 3-7 lists specific corrosion species, requested by WSE. None of the limits are exceeded in any of these tables. 
Table 3-1. Results for the 3rd Quarter 2007 Tank 50 Slurry Samples and WAC Limits for Chemical Contaminants Listed in Attachment 8.1 of the Saltstone WAC, Revision 7

\begin{tabular}{|c|c|c|c|c|}
\hline Chemical Species & Method & $\frac{\begin{array}{c}\text { Average } \\
\text { Concentration }\end{array}}{(\mathrm{mg} / \mathrm{L})}$ & \% RSD & $\frac{\text { WAC LIMIT }}{\underline{(\mathrm{mg} / \mathrm{L})}}$ \\
\hline Ammonium $\left(\mathrm{NH}_{4}^{+}\right)$ & IC & $<1.00 \mathrm{E}+03$ & -- & $7.13 \mathrm{E}+03$ \\
\hline Carbonate $\left(\mathrm{CO}_{3}{ }^{-2}\right)$ & TIC & $4.19 \mathrm{E}+03^{\mathrm{a}}$ & 0.36 & $1.45 E+05$ \\
\hline Chloride ( $\left.\mathrm{Cl}^{-}\right)$ & $\mathrm{IC}$ & $<5.00 \mathrm{E}+02$ & -- & $9.68 \mathrm{E}+03$ \\
\hline Fluoride $\left(\mathrm{F}^{-}\right)$ & IC & $<5.00 \mathrm{E}+02$ & -- & $4.94 \mathrm{E}+03$ \\
\hline Free Hydroxide $\left(\mathrm{OH}^{-}\right)$ & Total base & $2.22 \mathrm{E}+04^{\mathrm{a}}$ & 2.34 & $1.91 \mathrm{E}+05$ \\
\hline Nitrate $\left(\mathrm{NO}_{3}{ }^{-}\right)$ & $\mathrm{IC}$ & $1.88 \mathrm{E}+05$ & 7.27 & $5.29 \mathrm{E}+05$ \\
\hline Nitrite $\left(\mathrm{NO}_{2}\right)^{-}$ & IC & $1.50 \mathrm{E}+03$ & 6.35 & $2.59 \mathrm{E}+05$ \\
\hline Oxalate $\left(\mathrm{C}_{2} \mathrm{O}_{4}^{-2}\right)$ & IC & $9.15 \mathrm{E}+02$ & 2.73 & $3.30 \mathrm{E}+04$ \\
\hline Phosphate $\left(\mathrm{PO}_{4}^{-3}\right)$ & ICP-ES & $2.02 \mathrm{E}+02$ & 3.69 & $3.56 \mathrm{E}+04$ \\
\hline Sulfate $\left(\mathrm{SO}_{4}{ }^{-2}\right)$ & $\mathrm{IC}$ & $<5.00 \mathrm{E}+02$ & -- & $6.89 \mathrm{E}+04$ \\
\hline Arsenic (As) & AA & $5.35 \mathrm{E}-02$ & 0.49 & $7.50 \mathrm{E}+02$ \\
\hline Barium (Ba) & ICP-ES & $<1.23 \mathrm{E}+00$ & -- & $7.50 \mathrm{E}+02$ \\
\hline Cadmium (Cd) & ICP-ES & $<1.60 \mathrm{E}+00$ & -- & $3.75 \mathrm{E}+02$ \\
\hline Chromium (Cr) & ICP-ES & $1.15 \mathrm{E}+01$ & 8.08 & $1.50 \mathrm{E}+03$ \\
\hline Lead $(\mathrm{Pb})$ & ICP-MS & $8.79 \mathrm{E}-01$ & 6.90 & $7.50 \mathrm{E}+02$ \\
\hline Mercury (Hg) & $\mathrm{AA}$ & $2.60 \mathrm{E}+01$ & 3.55 & $3.25 \mathrm{E}+02$ \\
\hline Selenium (Se) & AA & $<1.07 \mathrm{E}-01$ & -- & $4.50 \mathrm{E}+02$ \\
\hline Silver (Ag) & ICP-ES & $<5.68 \mathrm{E}+00$ & -- & $7.50 \mathrm{E}+02$ \\
\hline Aluminum (AI) & ICP-ES & $7.08 \mathrm{E}+03$ & 2.76 & $1.41 \mathrm{E}+05$ \\
\hline Butanol \& Isobutanol & VOA & $<2.50 \mathrm{E}-01$ & -- & $2.25 \mathrm{E}+03$ \\
\hline Isopropanol & VOA & $<2.50 \mathrm{E}-01$ & -- & $2.25 \mathrm{E}+03$ \\
\hline Phenol & SVOA & $1.50 \mathrm{E}+00$ & $20 \%$ unc & $7.50 \mathrm{E}+02$ \\
\hline Total organic carbon & TOC & $6.40 \mathrm{E}+02^{\mathrm{a}}$ & 10.0 & $5.00 \mathrm{E}+03$ \\
\hline $\begin{array}{c}\text { Tetraphenylborate } \\
\text { (TPB) }\end{array}$ & HPLC & $<5.00 \mathrm{E}+00$ & -- & $3.00 \mathrm{E}+01$ \\
\hline
\end{tabular}

a. Only supernate was analyzed. 
Table 3-2. Results for the 3rd Quarter 2007 Tank 50 Slurry Samples and WAC Targets for Chemical Contaminants Listed in Attachment 8.2 of the Saltstone WAC, Revision 7

\begin{tabular}{|c|c|c|c|c|}
\hline Chemical Species & Method & $\frac{\begin{array}{c}\text { Average } \\
\text { Concentration }\end{array}}{\underline{(\mathrm{mg} / \mathrm{L})}}$ & \% RSD & $\frac{\underline{\text { WAC }}}{\text { TARGET }}$ \\
\hline Boron (B) & ICP-ES & $6.88 \mathrm{E}+01$ & 1.70 & $9.00 \mathrm{E}+02$ \\
\hline Cobalt (Co) & ICP-MS & $<1.54 \mathrm{E}-01$ & -- & $9.00 \mathrm{E}+02$ \\
\hline Copper (Cu) & ICP-ES & $<5.09 \mathrm{E}+00$ & -- & $9.00 \mathrm{E}+02$ \\
\hline Iron (Fe) & ICP-ES & $2.18 \mathrm{E}+02$ & 3.79 & $6.00 \mathrm{E}+03$ \\
\hline Potassium (K) & ICP-ES & $1.92 \mathrm{E}+02$ & 2.58 & $3.67 E+04$ \\
\hline Lithium (Li) & ICP-ES & $<5.74 \mathrm{E}+00$ & -- & $9.00 E+02$ \\
\hline Manganese (Mn) & ICP-ES & $1.54 \mathrm{E}+02$ & 3.58 & $9.00 \mathrm{E}+02$ \\
\hline Molybdenum (Mo) & ICP-ES & $<6.20 \mathrm{E}+00$ & -- & $9.00 \mathrm{E}+02$ \\
\hline Nickel (Ni) & ICP-ES & $1.62 \mathrm{E}+01$ & 9.58 & $9.00 \mathrm{E}+02$ \\
\hline Silicon (Si) & ICP-ES & $1.33 \mathrm{E}+02$ & 8.78 & $1.29 \mathrm{E}+04$ \\
\hline Strontium (Sr) & ICP-ES & $<8.17 \mathrm{E}+00$ & -- & $9.00 \mathrm{E}+02$ \\
\hline Zinc (Zn) & ICP-ES & $1.90 \mathrm{E}+01$ & & $9.75 E+02$ \\
\hline Benzene & VOA & $<2.50 \mathrm{E}-01$ & -- & $3.75 \mathrm{E}+02$ \\
\hline Methanol & VOA & a. & & $2.25 E+02$ \\
\hline Toluene & VOA & $<2.50 \mathrm{E}-01$ & -- & $3.75 \mathrm{E}+02$ \\
\hline TributylPhosphate (TBP) & SVOA & $1.70 \mathrm{E}-01$ & $20 \%$ uncert & $3.00 \mathrm{E}+02$ \\
\hline EDTA & HPLC & $<1.00 \mathrm{E}+02$ & -- & $3.75 E+02$ \\
\hline
\end{tabular}

a. Currently a routine method for detecting this species does not exist in AD.

As seen from the above tables, none of the contaminants exceed the WAC limit or targets imposed. Although nitrate (Table 3-1) and manganese (Table 3-2) did not exceed the WAC limit and target, respectively, they are within 3 times the criteria compared with the other constituents and should be monitored in future WAC results. Along with detecting small concentrations of phenol and TBP, the SVOA method also detected branched alkyl benzenes at a concentration of $4.5 \mathrm{mg} / \mathrm{L}$, dodecane at a concentration of $0.39 \mathrm{mg} / \mathrm{L}$ and tridecane at a concentration of $0.32 \mathrm{mg} / \mathrm{L}$. Branched alkyl benzenes are characteristically found in scintillation cocktails.

Table 3-3 contains information for the radioactive contaminants and their limits listed in Attachment 8.3 of the WAC, revision $7 .^{1}$ 
Table 3-3. Results for 3rd Quarter 2007 Tank 50 Slurry Samples and WAC Limits for Radionuclide Contaminants Listed in Attachment 8.3 of the Saltstone WAC, Revision 7.

\begin{tabular}{|c|c|c|c|c|}
\hline$\underline{\text { Radionuclide }}$ & $\underline{\text { Method }}$ & $\frac{\underline{\text { Average }}}{\text { Concentration }} \frac{(\mathrm{pCi} / \mathrm{mL})}{}$ & \% RSD & $\frac{\text { WAC LIMIT }}{\underline{(\mathrm{pCi} / \mathrm{mL})}}$ \\
\hline Tritium $\left({ }^{3} \mathbf{H}\right)$ & Tritium counting & $1.93 \mathrm{E}+03$ & 2.99 & $5.63 E+05$ \\
\hline Carbon-14 $\left({ }^{14} \mathrm{C}\right)$ & $\begin{array}{l}\text { C-14 Liquid } \\
\text { scintillation }\end{array}$ & $<6.35 \mathrm{E}+01$ & -- & $1.13 E+05$ \\
\hline Nickel-63 $\left({ }^{63} \mathrm{Ni}\right)$ & Ni 59/63 & $3.47 \mathrm{E}+02$ & 40.0 & $1.13 E+05$ \\
\hline Strontium-90 $\left({ }^{90} \mathrm{Sr}\right)$ & $\begin{array}{l}\text { Sr-90 Liquid } \\
\text { scintillation }\end{array}$ & $2.68 \mathrm{E}+05$ & 14.3 & $2.25 \mathrm{E}+07$ \\
\hline Technetium-99 $\left({ }^{99} \mathrm{Tc}\right)$ & $\begin{array}{c}\text { Tc-99 Liquid } \\
\text { scintillation }\end{array}$ & $4.43 \mathrm{E}+02$ & 0.65 & $4.22 \mathrm{E}+05$ \\
\hline Iodine-129 $\left({ }^{129} \mathrm{I}\right)$ & $\begin{array}{c}\text { I-129 } \\
\text { (w/ separation) Liquid } \\
\text { scintillation }\end{array}$ & $3.23 \mathrm{E}+00$ & 41.5 & $1.13 E+03$ \\
\hline Cesium-137 $\left({ }^{137} \mathrm{Cs}\right)$ & Gamma Scan & $5.02 \mathrm{E}+05$ & 2.59 & $4.75 \mathrm{E}+07$ \\
\hline Uranium-233 $\left({ }^{233} \mathrm{U}\right)$ & ICP-MS & $<1.66 \mathrm{E}+02$ & -- & $1.13 E+04$ \\
\hline Uranium-235 $\left({ }^{235} \mathrm{U}\right)$ & ICP-MS & $7.31 \mathrm{E}-01$ & 5.75 & $1.13 E+02$ \\
\hline Plutonium-241 ( $\left.{ }^{241} \mathrm{Pu}\right)$ & $\begin{array}{l}\text { Pu238/241 Liquid } \\
\text { scintillation }\end{array}$ & $4.56 \mathrm{E}+03$ & 14.0 & $8.38 \mathrm{E}+05$ \\
\hline Total Alpha & $\begin{array}{l}\text { Rad screen liquid } \\
\text { scintillation }\end{array}$ & $6.74 \mathrm{E}+03^{* *}$ & 17.09 & $2.50 \mathrm{E}+05$ \\
\hline
\end{tabular}

None of the values in this table of radionuclide contaminants exceeds the WAC limits imposed. 
Table 3-4 contains information for the radioactive contaminants and their targets listed in Attachment 8.4 of the WAC, revision $7 .^{1}$

Table 3-4. Results for 3rd Quarter 2007 Tank 50 Slurry Samples and WAC Targets for Radionuclide Contaminants Listed in Attachment 8.4 of the Saltstone WAC, Revision 7.

\begin{tabular}{|c|c|c|c|c|}
\hline$\underline{\text { Radionuclide }}$ & Method & $\frac{\begin{array}{c}\text { Average } \\
\text { Concentration }\end{array}}{\underline{\text { (pCi/mL) }}}$ & \%RSD & $\frac{\underline{\text { WAC }}}{\text { TARGET }}$ \\
\hline Cobalt-60 $\left({ }^{60} \mathrm{Co}\right)$ & $\begin{array}{l}\text { Gamma scan } \\
\text { (Cs removed) }\end{array}$ & $2.03 \mathrm{E}+01$ & 2.33 & $1.13 E+06$ \\
\hline Nickel-59 $\left({ }^{59} \mathrm{Ni}\right)$ & $\mathrm{Ni} 59 / 63$ & $<3.59 \mathrm{E}+01$ & -- & $1.13 E+05$ \\
\hline Selenium-79 $\left({ }^{79} \mathrm{Se}\right)$ & $\mathrm{Se} 79$ & $1.49 \mathrm{E}+03$ & 2.60 & $1.90 \mathrm{E}+04$ \\
\hline Niobium-93m $\left({ }^{93 m} \mathrm{Nb}\right)$ & ICP-MS & $4.43 \mathrm{E}+02$ & 14.6 & $2.85 E+06$ \\
\hline Niobium-94 $\left({ }^{94} \mathrm{Nb}\right)$ & $\begin{array}{l}\text { Gamma scan } \\
\text { (Cs removed) }\end{array}$ & $<1.11 \mathrm{E}+01$ & -- & $1.53 E+04$ \\
\hline Molybdenum-93 $\left({ }^{93} \mathrm{Mo}\right)$ & ICP-MS & $1.94 \mathrm{E}+05$ & 14.6 & $1.18 E+07$ \\
\hline Ruthenium-106 $\left({ }^{106} \mathrm{Ru}\right)$ & $\begin{array}{l}\text { Gamma scan } \\
\text { (Cs removed) }\end{array}$ & $<1.15 \mathrm{E}+02$ & -- & $1.13 E+06$ \\
\hline Antimony-125 ( $\left({ }^{125} \mathrm{Sb}\right)$ & Gamma scan & $3.79 \mathrm{E}+04$ & 2.15 & $2.25 E+06$ \\
\hline Tin-126 $\left({ }^{126} \mathrm{Sn}\right)$ & $\begin{array}{l}\text { Gamma scan } \\
\text { (Cs removed) }\end{array}$ & $<8.15 \mathrm{E}+01$ & -- & $1.80 E+04$ \\
\hline Cesium-134 $\left({ }^{134} \mathrm{Cs}\right)$ & Gamma Scan & $<7.25 \mathrm{E}+01$ & -- & $1.13 E+06$ \\
\hline Cesium-135 $\left({ }^{135} \mathrm{Cs}\right)$ & ICP-MS & $6.45 \mathrm{E}+01$ & 10.8 & $1.13 E+06$ \\
\hline Cerium-144 $\left({ }^{144} \mathrm{Ce}\right)$ & $\begin{array}{c}\text { Gamma scan } \\
\text { (Cs removed) }\end{array}$ & $<2.07 \mathrm{E}+02$ & -- & $1.13 E+05$ \\
\hline Promethium-147 ( $\left.{ }^{147} \mathrm{Pm}\right)$ & $\begin{array}{c}\text { Pm147/Sm151 } \\
\text { Liquid scintillation }\end{array}$ & $1.76 \mathrm{E}+03$ & 20.1 & $5.63 E+06$ \\
\hline Samarium-151 $\left({ }^{151} \mathrm{Sm}\right)$ & $\begin{array}{c}\text { Pm147/Sm151 } \\
\text { Liquid scintillation }\end{array}$ & $1.23 \mathrm{E}+03$ & 3.65 & $2.25 E+04$ \\
\hline Europium-154 $\left({ }^{154} \mathrm{Eu}\right)$ & $\begin{array}{c}\text { Gamma scan } \\
\text { (Cs removed) }\end{array}$ & $7.16 \mathrm{E}+02$ & 0.63 & $2.25 \mathrm{E}+06$ \\
\hline Europium-155 ( $\left.{ }^{155} \mathbf{E u}\right)$ & $\begin{array}{l}\text { Gamma scan } \\
\text { (Cs removed) }\end{array}$ & $<2.28 \mathrm{E}+02$ & -- & $1.13 E+04$ \\
\hline Radium-226 $\left({ }^{226} \mathrm{Ra}\right)$ & $\begin{array}{l}\text { Gamma scan } \\
\text { (Cs removed) }\end{array}$ & $<7.97 \mathrm{E}+02$ & -- & $7.97 E+03$ \\
\hline
\end{tabular}


Table 3-4. Results for 3rd Quarter 2007 Tank 50 Slurry Samples and WAC Targets for Radionuclide Contaminants Listed in Attachment 8.4 of the Saltstone WAC, Revision 7. (Continued)

\begin{tabular}{|c|c|c|c|c|}
\hline$\underline{\text { Radionuclide }}$ & Method & 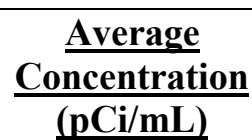 & \%RSD & $\frac{\frac{\text { WAC }}{\text { TARGET }}}{\text { (pCi/mL) }}$ \\
\hline Thorium-229 $\left({ }^{229} \mathrm{Th}\right)$ & ICP-MS & $<3.65 \mathrm{E}+03$ & -- & $1.63 E+05$ \\
\hline Thorium-230 $\left({ }^{230} \mathrm{Th}\right)$ & ICP-MS & $<3.61 \mathrm{E}+02$ & -- & $6.26 \mathrm{E}+03$ \\
\hline Thorium-232 $\left({ }^{232} \mathrm{Th}\right)$ & ICP-MS & $1.29 \mathrm{E}-02$ & 38.8 & $2.88 E+03$ \\
\hline Uranium-232 $\left({ }^{232} \mathrm{U}\right)$ & $\mathrm{U} 232$ & $<8.74 \mathrm{E}-01$ & -- & $1.71 \mathrm{E}+05$ \\
\hline Uranium-234 $\left({ }^{234} U\right)$ & ICP-MS & $<1.07 \mathrm{E}+02$ & -- & $1.13 E+04$ \\
\hline Uranium-236 $\left({ }^{236} \mathrm{U}\right)$ & ICP-MS & $5.67 \mathrm{E}+00$ & 7.19 & $1.13 E+04$ \\
\hline Uranium-238 $\left({ }^{238} \mathrm{U}\right)$ & ICP-MS & $2.24 \mathrm{E}+00$ & 2.32 & $1.13 E+04$ \\
\hline Neptunium-237 $\left({ }^{237} \mathrm{~Np}\right)$ & ICP-MS & $<1.21 \mathrm{E}+01$ & -- & $2.50 \mathrm{E}+05$ \\
\hline Plutonium-238 $\left({ }^{238} \mathrm{Pu}\right)$ & $\begin{array}{c}\mathrm{Pu} 238 / 241 \\
\mathrm{Pu} \text { alpha PHA }\end{array}$ & $1.33 \mathrm{E}+04$ & 21.6 & $2.50 \mathrm{E}+05$ \\
\hline Plutonium-239 $\left({ }^{239} \mathrm{Pu}\right)$ & $\begin{array}{c}\mathrm{Pu} 238 / 241 \\
\mathrm{Pu} \text { alpha } \mathrm{PHA}\end{array}$ & $9.17 \mathrm{E}+02$ & 24.0 & $2.50 \mathrm{E}+05$ \\
\hline Plutonium-240 $\left({ }^{240} \mathrm{Pu}\right)$ & $\begin{array}{c}\text { Pu238/241 } \\
\text { Pu alpha PHA }\end{array}$ & $9.17 \mathrm{E}+02$ & 24.0 & $2.50 \mathrm{E}+05$ \\
\hline Plutonium-242 $\left({ }^{242} \mathrm{Pu}\right)$ & ICP-MS & $<1.64 \mathrm{E}+02$ & -- & $2.50 \mathrm{E}+05$ \\
\hline Plutonium-244 $\left({ }^{244} \mathrm{Pu}\right)$ & ICP-MS & $<3.03 \mathrm{E}-01$ & -- & $7.02 \mathrm{E}+04$ \\
\hline Americium-241 ( $\left.{ }^{241} \mathrm{Am}\right)$ & $\mathrm{Am} / \mathrm{Cm}$ & $1.70 \mathrm{E}+03$ & 2.84 & $2.50 \mathrm{E}+05$ \\
\hline Americium-242m $\left({ }^{242 m} \mathrm{Am}\right)$ & $\mathrm{Am} / \mathrm{Cm}$ & $2.03 \mathrm{E}+00$ & 9.39 & $4.50 \mathrm{E}+05$ \\
\hline Americium-243 ( $\left.{ }^{243} \mathrm{Am}\right)$ & $\mathrm{Am} / \mathrm{Cm}$ & $2.39 \mathrm{E}+01$ & 5.60 & $2.50 \mathrm{E}+05$ \\
\hline Curium-242 $\left({ }^{242} \mathrm{Cm}\right)$ & $\mathrm{Am} / \mathrm{Cm}$ & $1.68 \mathrm{E}+00$ & 9.42 & $1.13 E+04$ \\
\hline Curium-244 $\left({ }^{244} \mathrm{Cm}\right)$ & $\mathrm{Am} / \mathrm{Cm}$ & $4.46 \mathrm{E}+03$ & 10.8 & $2.50 \mathrm{E}+05$ \\
\hline Curium-245 $\left({ }^{245} \mathrm{Cm}\right)$ & $\mathrm{Am} / \mathrm{Cm}$ & $<7.16 \mathrm{E}+01$ & -- & $2.25 \mathrm{E}+05$ \\
\hline
\end{tabular}

None of the values in Table 3-4 exceeds the WAC targets imposed. The value of Nb-93m is taken from the ICP-MS results of mass 93. All of the signal at mass 93 can be assigned to Zr-93 which is in secular equilibrium with $\mathrm{Nb}-93 \mathrm{~m}$. Consequently, the maximum activity of the $\mathrm{Nb}-93 \mathrm{~m}$ is equal to that of the $\mathrm{Zr}$ 93. Therefore the specific activity of $\mathrm{Zr}-93(2.51 \mathrm{E}-03 \mathrm{Ci} / \mathrm{g})$ is used when calculating the maximum concentration of $\mathrm{Nb}-93 \mathrm{~m}$. The concentration of Cs-135 is calculated by assuming that all of the mass at 135 was contributed by cesium. In the ICP-MS analysis of the digested slurry samples, no analyte was detected at mass 229. Because the Th 229 and 230 isotopes have identical electronic structures, and the Th-230 was reported at the MDL, the MDL for Th-229 and Th-230 were assumed to be equal. In the case of mass 244, that was assumed to be all $\mathrm{Pu}$ (although it was at the MDL for the instrument.) The $\mathrm{Pu} 239 / 240$ is given as a total of the mass 239 and 240. For the individual masses, it was the concentration for each, mass 239 and 240, that were determined using the specific activity for the individual isotopes of $\mathrm{Pu}$. In either case, the concentrations did not exceed the WAC limit. 
Table 3-5 shows the processing criteria that must be met from the WAC.

Table 3-5. Results for the 3rd Quarter 2007 Slurry Samples for the Saltstone Processing Criteria WAC Limits, Listed in Table 4 of the Saltstone WACS, Revision 7.

\begin{tabular}{|c|c|c|c|}
\hline Processing Criterion & Method & $\underline{\text { Value }}$ & \%RSD \\
\hline $\mathrm{pH}>10$ & Calculated & $>13$ & - \\
\hline $3.5 \mathrm{M}<\left[\mathrm{Na}^{+}\right]<7.0 \mathrm{M}$ & ICP-ES & $4.51 \mathrm{M}$ & 2.86 \\
\hline Total Insoluble Solids $<15 \mathrm{wt} \%$ & Calculated & $0.121 \mathrm{wt} \%$ & \\
\hline
\end{tabular}

All of the processing criteria fall within the WAC limits. The $\mathrm{pH}$ was calculated using the free base concentration $\left(\mathrm{OH}^{-}\right)$. The value for the total insoluble solids was calculated by Erich Hansen from experimentally determined values for total solids and dissolved solids in the slurry supernate. The equation for this is given in Reference 5. Additional discussion of the sampling and solids analysis is in Reference 6. 
Table 3-6 contains constituents listed in the TTR but not necessarily the WAC and also those constituents for the EPA Toxic Characterization Leaching Procedure and Underlying Hazardous Constituent work (TCLP/UHC). ${ }^{4}$ The limits listed were imposed to aid in supporting the TCLP/UHC work.

Table 3-6. Requests for constituents for TCLP/UHC support as well as from the TTR for Tank 50 Slurry Samples

\begin{tabular}{|c|c|c|c|c|}
\hline Constituent & Method & $\begin{array}{c}\text { Average } \\
\text { Concentration }\end{array}$ & \%RSD & $\underline{\text { Limit }}$ \\
\hline Antimony $(\mathbf{S b})^{\mathbf{b}}$ & ICP-MS & $\overline{2.34 \mathrm{E}-01 \mathrm{mg} / \mathrm{L}}$ & 6.9 & $23 \mathrm{mg} / \mathrm{L}$ \\
\hline Arsenic (As) & AA & $5.32 \mathrm{E}-02 \mathrm{mg} / \mathrm{L}$ & 0.49 & $100 \mathrm{mg} / \mathrm{L}$ \\
\hline Barium (Ba) & ICP-ES & $<1.23 \mathrm{E}+00 \mathrm{mg} / \mathrm{L}$ & -- & $420 \mathrm{mg} / \mathrm{L}$ \\
\hline Benzene $\left(\mathrm{CH}_{3} \mathrm{OH}\right)$ & VOA & $<2.50 \mathrm{E}-01 \mathrm{mg} / \mathrm{L}$ & -- & $10 \mathrm{mg} / \mathrm{L}$ \\
\hline Beryllium (Be) $^{\mathbf{b}}$ & ICP-ES & $<2.17 \mathrm{E}-01 \mathrm{mg} / \mathrm{L}$ & -- & $24.4 \mathrm{mg} / \mathrm{L}$ \\
\hline Cadmium (Cd) & ICP-ES & $<1.60 \mathrm{E}+00 \mathrm{mg} / \mathrm{L}$ & -- & $2.2 \mathrm{mg} / \mathrm{L}$ \\
\hline Chromium (Cr) & ICP-ES & $1.15 \mathrm{E}+01 \mathrm{mg} / \mathrm{L}$ & 8.08 & $12 \mathrm{mg} / \mathrm{L}$ \\
\hline Cyanide $(\mathrm{CN})^{\mathrm{b}}$ & a. & a. & -- & -- \\
\hline Lead $(\mathrm{Pb})$ & ICP-MS & $8.79 \mathrm{E}-01 \mathrm{mg} / \mathrm{L}$ & 6.90 & $15 \mathrm{mg} / \mathrm{L}$ \\
\hline Mercury (Hg) & $\mathrm{AA}$ & $2.60 \mathrm{E}+01 \mathrm{mg} / \mathrm{L}$ & 3.55 & $0.5 \mathrm{mg} / \mathrm{L}$ \\
\hline Phenol $\left(\mathrm{C}_{6} \mathrm{H}_{5} \mathrm{OH}\right)$ & SVOA & $1.50 \mathrm{E}+00 \mathrm{mg} / \mathrm{L}$ & & $6.2 \mathrm{mg} / \mathrm{L}$ \\
\hline Selenium (Se) & AA & $<1.07 \mathrm{E}-01 \mathrm{mg} / \mathrm{L}$ & -- & $114 \mathrm{mg} / \mathrm{L}$ \\
\hline Silver (Ag) & ICP-ES & $<5.68 \mathrm{E}+00 \mathrm{mg} / \mathrm{L}$ & -- & $2.8 \mathrm{mg} / \mathrm{L}$ \\
\hline Thallium (TI) ${ }^{\mathrm{b}}$ & ICP-MS & $<3.25 \mathrm{E}-01 \mathrm{mg} / \mathrm{L}$ & -- & $4.0 \mathrm{mg} / \mathrm{L}$ \\
\hline Total Beta $^{b}$ & $\begin{array}{c}\text { Liquid } \\
\text { Scintillation } \\
\text { Counting }\end{array}$ & $1.99 \mathrm{E}+05 \mathrm{pCi} / \mathrm{mL}$ & 17.8 & -- \\
\hline Total Gamma $^{b}$ & See Text & $5.42 \mathrm{E}+05 \mathrm{pCi} / \mathrm{mL}$ & 2.40 & -- \\
\hline Density (slurry) ${ }^{b}$ & Measured & $1.2288 \mathrm{~g} / \mathrm{mL}$ & & \\
\hline Total Solids ${ }^{\mathrm{b}}$ & Measured & 27.379 wt $\%$ & & \\
\hline
\end{tabular}

a. Currently a routine method for detecting this species does not exist in AD.

b. Requested by TTR.

Antimony was calculated by summing the masses of 121 and 123 from the ICP-MS results. This was more sensitive than the ICP-ES results. Thallium was also calculated by summing the masses of 203 and 205 from the ICP-MS results. Currently, no method exists in AD for the detection of cyanide. The total gamma activity was calculated by summing the measured gamma activity of the major gamma emitters, detected by gamma pulse height analysis of the dissolved slurry samples. The major gamma emitters were: Co-60, Cs-137, Sb-125, Eu-154, and Am-241.

The tank corrosion species can be found in Table 3-7. All of the results except those for specific gravity and $\mathrm{Ba}-137 \mathrm{~m}$ can be found in the above tables but are listed in Table 3-7 for reader convenience. The method for determining specific gravity and Ba-137m are discussed below. 
WSRC-TR-2008-00080

Revision 1

Table 3-7. Requests from the WSE for Corrosion Species from Tank 50 Slurry Samples.

\begin{tabular}{|c|c|c|c|}
\hline Constituent & Method & $\begin{array}{c}\text { Average } \\
\text { Concentration }\end{array}$ & \%RSD \\
\hline Specific Gravity & a. & 1.2317 & \\
\hline Nitrite $\left.\mathbf{( N O}^{-}\right)^{-}$ & IC & $1.50 \mathrm{E}+03 \mathrm{mg} / \mathrm{L}$ & 6.35 \\
\hline Nitrate $\left.\mathbf{( N O}^{-}\right)^{-}$ & IC & $1.88 \mathrm{E}+05 \mathrm{mg} / \mathrm{L}$ & 7.27 \\
\hline Free Hydroxide $\left(\mathbf{O H}^{-}\right)$ & Total Base & $2.22 \mathrm{E}+04 \mathrm{mg} / \mathrm{L}$ & 2.34 \\
\hline Ba-137m & b. & $4.74 \mathrm{E}+05 \mathrm{pCi} / \mathrm{mL}$ & 2.59 \\
\hline Total Gamma & Gamma Scan & $5.42 \mathrm{E}+05 \mathrm{pCi} / \mathrm{mL}$ & 2.40 \\
\hline
\end{tabular}

a. Calculated from the measured density and density of water at $22.4{ }^{\circ} \mathrm{C}$. See text below.

b. Calculated from the measured concentration of its radioactive parent Cs-137. See text below.

Specific gravity was calculated by taking the density of the slurry $(1.2288 \mathrm{~g} / \mathrm{mL})$ and dividing it by the density of water at the temperature it was measured, $22.4{ }^{\circ} \mathrm{C}(0.997679 \mathrm{~g} / \mathrm{mL})$. The radionuclide Ba$137 \mathrm{~m}$ with its half-life of 2.55 minutes $^{7}$ is the radioactive daughter of $94.7 \%$ of the beta decay ${ }^{7}$ of Cs- $^{-137}$, which has a half-life of 30.07 years. ${ }^{7}$ (Cs-137 decays 5.3\% of the time to stable Ba-137. ${ }^{7}$ ) Because the half-life of $\mathrm{Ba}-137 \mathrm{~m}$ is so short compared to Cs-137, the two radionuclides are in secular equilibrium. Thus the activity of Ba-137m is $94.7 \%$ of the activity of the Cs-137 or $4.74 \mathrm{E}+05 \mathrm{pCi} / \mathrm{mL}$. 


\subsection{CONCLUSIONS}

None of the results for the 3rd Quarter WAC targets or limits were exceeded. Nitrate and manganese are within 3 times their WAC target/limit. 


\subsection{REFERENCES}

1. Culbertson, B. H., Waste Acceptance Criteria for Aqueous Waste Sent to the Z-Area Saltstone Production Facility (U), X-SD-Z-00001, Revision 7, February 2007.

2. Ray, J. W., Technical Task Request, SSF-TTR-2007-0005, Revision 0, March 2007.

3. Zeigler, K. E., and Bibler, N. E., Task Technical and Quality Assurance Plan for the Tank 50 Waste Acceptance Criteria (WAC) Analysis April 2007, SRNL-ADD-2007-00299, Revision 0, May 2007.

4. Zeigler, K. E., and Bibler, N. E., Tank 50 Waste Acceptance Criteria (WAC) Analysis April 2007- Analytical Study Plan, SRNL-ADD-2007-00300, Revision 0, May 2007.

5. Zeigler, K. E., Bibler, N. E., and DiPrete, D. P., Characterization of Tank 50 Slurry for Saltstone Waste Acceptance Criteria, April 2007 Samples, WSRC-STI-2007-00554, November, 2007.

6. Hansen, E.K. and Cozzi, A.D., Saltstone Formulation Testing for 4Q2007 Start Up, SRNL-PSE2007-00227, October, 2007.

7. National Nuclear Data Center, www.nndc.bnl.gov, Version NUDAT 2.4 Brookhaven National Laboratory, 12/5/07. 


\subsection{ACKNOWLEDGEMENTS}

The authors wish to thank the following people for their assistance, helpful discussions, and quick turn around with the results from these samples: David Healy, Leigh Brown, Tom White, Steve Crump, Kathy White, Curtis Johnson, Mark Jones, CeCi DiPrete, Dave Diprete, Damon Click, and the technicians in Analytical Development. Also we thank Alex Cozzi, and Erich Hansen for the weight percent solids and density determinations. 


\section{Distribution:}

J. L. Adams,

A. T. Atseff,

A. B. Barnes,

M. J. Barnes,

S. B. Beck,

C. H. Beheler,

S. D. Burke,

H. H. Burns,

A. D. Cozzi,

L. M. Chandler,

C. C. DiPrete,

E. J. Freed,

J. C. Griffin,

E. K. Hansen,

J. R. Harbour,

S. D. Heath,

C. C. Herman,

P. J. Hill,

W. L. Isom,

C. J. Johnson,

M. K. Lancaster,

C. A. Langton,

K. R. Liner,

M. J. Mahoney,

J. E. Marra,

D. J. Martin,

C. A. Nash,

P. W. Norris,

J. E. Occhipinti, 704-S

E. Patten, 704-Z

J. W. Ray, 704-S

A. L. Richardson, $\quad$ 704-Z

L. B. Romanowski, 766-H

R. L. Salizzoni, $\quad$ 703-H
704-Z

$704-14 Z$

704-S

999-W

$773-\mathrm{A}$

$773-\mathrm{A}$

$704-56 \mathrm{H}$

$73-\mathrm{A}$

$9-W$

704-Z

999-W

766-H

$766-\mathrm{H}$

$704-14 Z$

766-H

704-S

766-H

703-H

$773-42 \mathrm{~A}$

704-Z
D. C. Sherburne, 704-S

A. V. Staub, 704-Z

K. E. Zeigler, 773-41A 